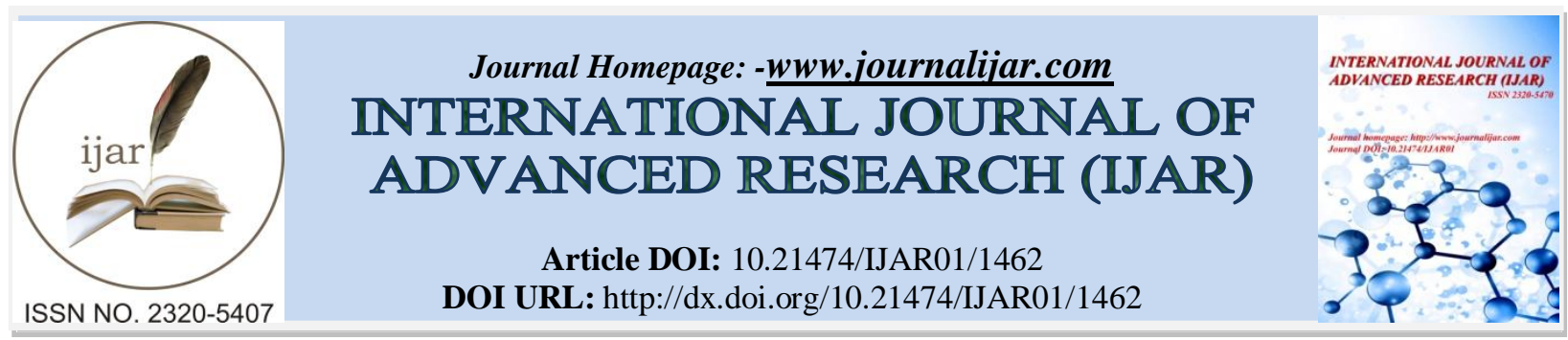

RESEARCH ARTICLE

\title{
TO STUDY THE MOTH (LEPIDOPTERA : HETEROCERA) FAUNA OF SAL FOREST IN MANDUWALA REGION, DEHRADUN.
}

Dinesh Kumar Bhardwaj, Lungkhul Mossang and Samim Rahman.

Deptt of Zoology, Dolphin (P.G.) Institute of Biomedical and Natural Sciences, Dehradun-248007

\section{Manuscript Info}

Manuscript History

Received: 12 July 2016

Final Accepted: 16 August 2016

Published: September 2016

Key words:-

Moth, Lepidoptera, Heterocera, fauna of Sal Forest.
Abstract

The Moths fauna has been studied in Manduwala region Dehradun. Collected insects and killed specimen were brought to laboratory, where they were spreaded on the spreading board and each specimen was pinned and oven dried at $60^{\circ} \mathrm{C}$ for 24 hours. After all these processes specimens finally kept in the insect box. To protect insects from ants and fungus naphthalene balls are placed in the insects box. The identification up to species level was done with the help of available entomological keys (Bell \& Scott 1937) with the help of colour digital photograph. In the present study total 6 families viz. Noctuidae, Geomertidae, Erebidae, Eupterotidae, Saturniidae and Sphingidae and their complete description has been discussed.

Copy Right, IJAR, 2016,. All rights reserved.

\section{Introduction:-}

Lepidoptera is a large order of insects that includes moths and butterflies. It is the second largest order in the class Insecta. Both butterflies and moths called as Lepidopterans. It is one of the most widespread and widely recognizable insect orders in the world. This order is generally divided into sub-orders Rhopalocera (Butterflies) and Heterocera (Moths). Comprising an estimated 174,250 species, in 126 families and 46 super families, they show many variations in their body structure. It is one of the most successful orders of insects that are present on planet earth. The class Insecta is arranged in 31 orders. The four major order are Coleopteran, Diptera, Hymenoptera \& Lepidoptera. The order Coleoptera(Beetles) are the largest of all and next is the Lepidoptera(Kumar 2013).Most moths are nocturnal. There are however exceptions, including the sometimes-diurnal Gypsy and the spectacular "Uraniidae" or Sunset moths. Like most other insect, moths are holometabolous, meaning they undergo complete metamorphosis. Moths also play a vital role in telling us about the health of our environment, like the canary in the coalmine. Since they are so widespread and found in so many different habitats, and are so sensitive to changes, moths are particularly useful as indicator species. Monitoring their numbers and ranges can give us vital clues to changes in our own environment, such as the effects of new farming practices, pesticides, air pollution and climate change. Sericulture is also one of the most valuable product of moth. Some moths, particularly their caterpillars, can be major agricultural pests in many parts of the world. Examples include corn borers and bollworms. The caterpillar of the gypsy moth (Lymantria dispar) causes severe damage to forests in the Northeastern United States, where it is an invasive species. In temperate climates, the codling moth causes extensive damage, especially to fruit farms. In tropical and subtropical climates, the diamondback moth (Plutella xylostella) is perhaps the most serious pest of brassicaceous crops. Several moths in the family Tineidae are commonly regarded as pests because theirlarvae eat fabric such as clothes and blankets made from natural proteinaceous fibers such as wool or silk.

Corresponding Author:-Dinesh Kumar Bhardwaj.

Address:-Deptt of Zoology, Dolphin Institute of Biomedical and Natural Sciences, Dehradun-248007. 


\section{Material and Method:-}

Moths of different species were collected during February- June 2016 from Sal forest (Shorea robusta) of Manduwala region. Dead moths were collected early in the morning everyday from the source of light e.g. halogen light, sodium light etc. at Dolphin Institute of Biomedical and Natural Sciences, Dehradun which is nearby \& connected by the sal forest. Collected insects were primarily identified using digital coloured photographs (Sondhi \& Sondhi, 2016), Primarily identified moths verified at Zoological Survey of India, Dehradun.

\section{Result and Discussion:-}

The Sal forest of manduwala region act as home of various insects of different orders viz. Coleoptera, Lepidoptera, Hymenoptera, Hemiptera, Odonata, Diptera, Orhoptera, Dictyoptera and Isoptera. The sweet fragrance of flower of $\mathrm{Sal}$ (Shorea robusta) tree used to attract the insect population. But this study is mainly focused \& based on the species diversity of moths(Lepidoptera : Heterocera) of Sal forest of Manduwala region in particular. The list of the collected moth species are given below in the table.1.

Table 1:- Collected species of Heterocera.

\begin{tabular}{|c|l|l|l|}
\hline SI. No. & \multicolumn{1}{|c|}{ Common name } & \multicolumn{1}{|c|}{ Species Zoological name } & \multicolumn{1}{c|}{ Family } \\
\hline 1. & Hawk moth & Agrius convolvuli & Sphingidae \\
\hline 2. & Cutworm & Agrotis innominata & Noctuidae \\
\hline 3. & Violet Gliding Hawkmoth & Ambulyx liturata & Sphingidae \\
\hline 4. & $\begin{array}{l}\text { Tussar moth/Oak } \\
\text { Silkmoth }\end{array}$ & Antheraea pernyi & Saturniidae \\
\hline 5. & Tropical Tiger moth & Asota caricae & Erebidae \\
\hline 6. & Willow beauty & Peribatodes rhomboidaria & Geometridae \\
\hline 7. & Emerald moth & Comibaena cassidara & Geometridae \\
\hline 8. & Giant lappet moth & Eupterotidae undata & Eupteroptidae \\
\hline 9. & & Ganisa plana & Euteroptidae \\
\hline 10. & & Meterana diatmeta & Noctuidae \\
\hline 11. & Tiger moth & Erebus hieroglyphica & Erebidae \\
\hline 12. & Tiger moth & Lemyra species & Erebidae \\
\hline
\end{tabular}

Total - 12 different species of moth has been collected from Manduwala region, out of which there are Erebidae 03, Sphingidae, Geometridae, Noctuidae, Eupterotidae, 02 and Saturniidae single species was observed. It has been seen that family Erebidae emeged as the largest observed species of the given region.

\section{Description of the species:-} Agrius convolvuli (Linneaus):-

Status:- common

Diagnostic characters:- Sexually dimorphic, female often considerably larger than male. Ground colour of forewing light to dark grey, with dark patches and markings which can be either extensive or absent. Caterpillars can be in a no. of different colours.

Wingspan:- 95-130mm.

Distribution:- the species is found from Europe to Asia including, India, China,Hong Kong ,UK, Italy, Philippines etc. and also over most of the Australia and Africa.

Host plant:-The caterpillar feed on many plants of family Convolvulaceae and Fabaceae, there are also records from other families. It also feed on Shorea robusta.

\section{Agrotis innominata, Hudson:-}

Status:- Rare

Diagnostic characters:- Major agricultural pests whose larvae hide by day time and emerge at night to feed. It cut down and partly eats the garden plants and crops especially, the seedlings.

Wingspan:- it has a wingspan of 36-39 $\mathrm{mm}$ for males and 28-31 $\mathrm{mm}$ for females.

Distribution:-Agrotis innominata is the only Agrotis species which is endemic to New Zealand. Found in the coastal regions of New Zealand.Agrius convolvuli andAgrotis innominataalso found in India.

Host plant:- The larvae feed on Ammophila arenaria (Marram grass) and Shorea robusta. 


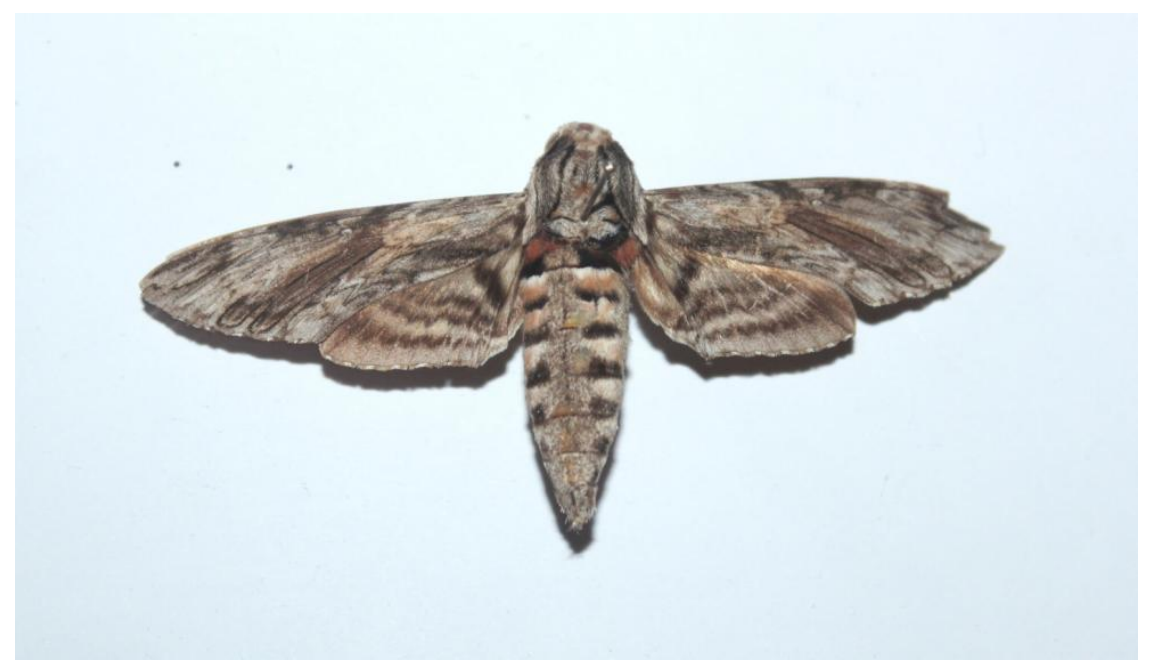

Fig 7:-Agrius convolvuli(Large hawk moth).

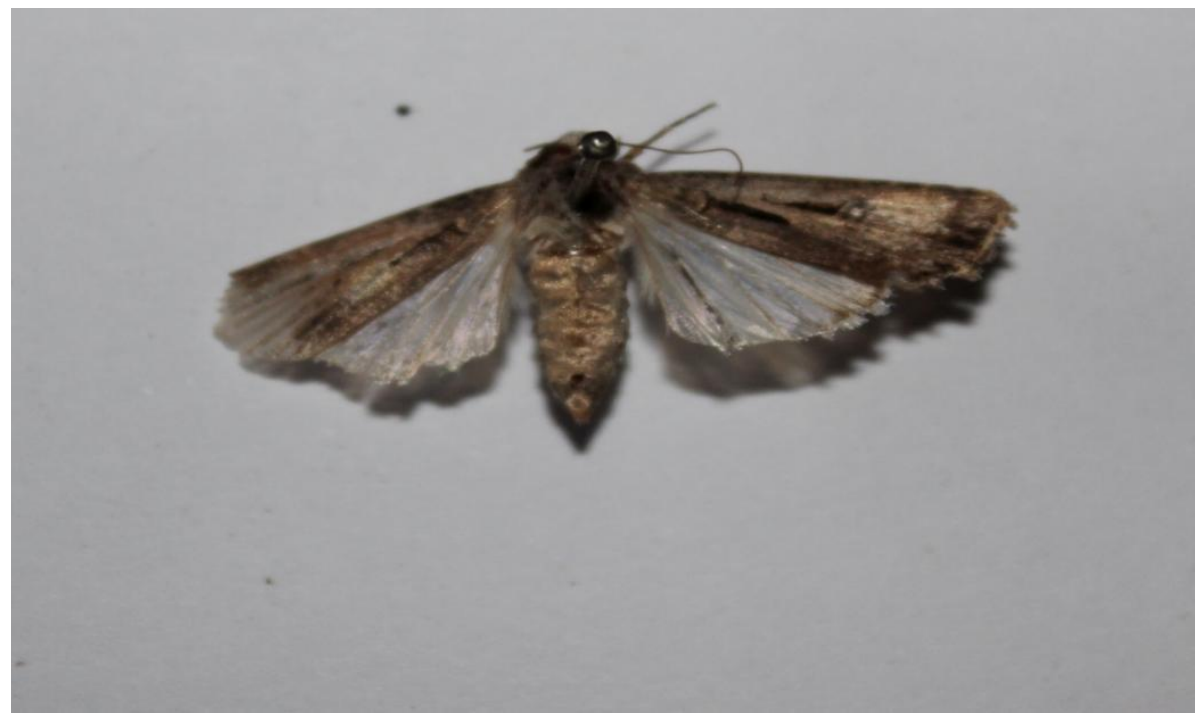

Fig 8:-Agrotis innominata(Cutworm).

\section{Ambulyx liturata, Butler:-}

Status:- Common

Wingspan:- 106-134mm.

Diagnostic characters:- It has the basal patch of hindwing upperside often pale tawny and not conspicuous, but there is more grey on the forewing of the male. The basal patch if the hindwing is less sharply defined both sexes, forewing upperside usually lacks the sub-basal coastal patch, but sometimes it is nearly as large as the spot near the anal margin. The underside of the body, palpi and wings and the upperside of the hindwing is deep orange fulvous. Distribution: it is found from India, Nepal, Bhutan, North-East India(Sikkim \& Assam), Myanmar, Thailand, Vietnam and China.

Host plant:- The larvae have been recorded to feed on Canarium album, Shorea robusta, Quercus and Castaniopsis

\section{Antheraea pernyi, (Guerin-Meneville):-}

Status:- Common

Wingspan:- 110-152 mm.

Diagnostic characters: - Large moth brightly coloured and usually tropical moth. Larvae spin silken cocoons from where silk of high quality can be derived. 
Distribution: they are originally from southern China. They have been distributed more widely across subtropical and tropical Asia. It can now be found in Europe.

Host plant:- Oak, Hornbeam, Chestnut, Plum, Sal and apple.

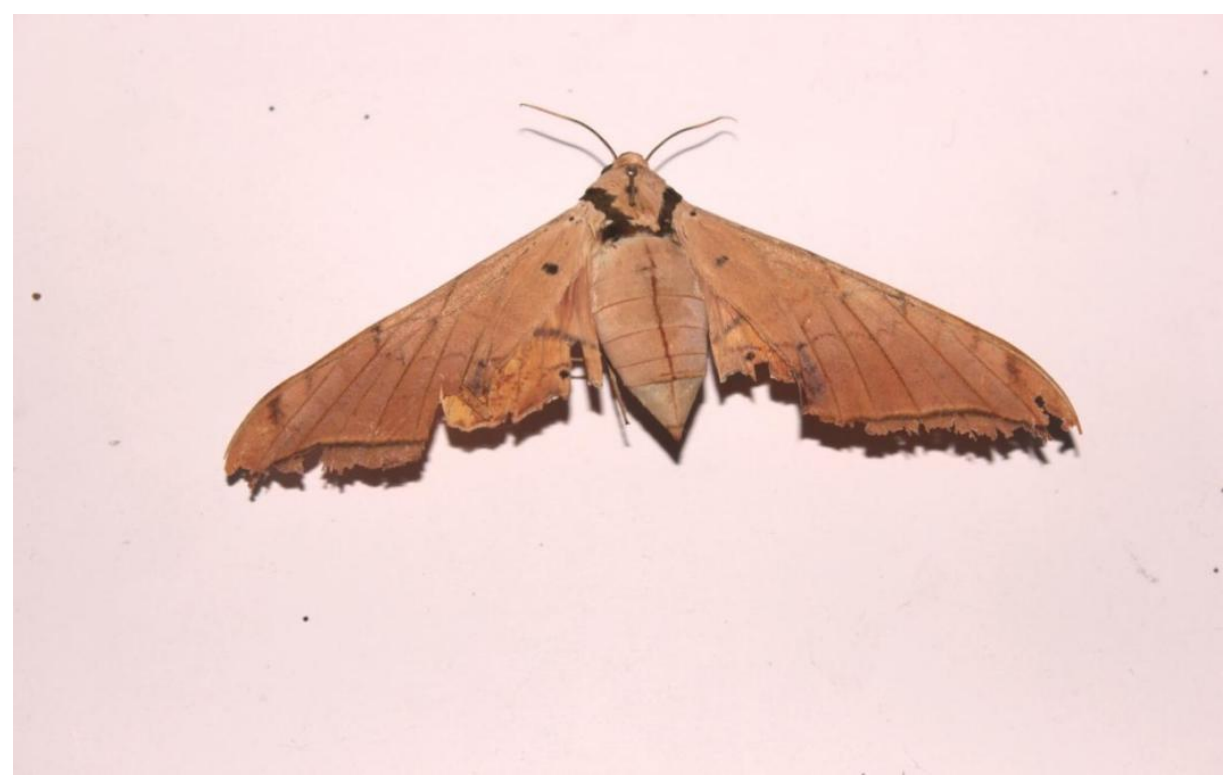

Fig 9:-Ambulyx liurata(Violet Gliding moth)

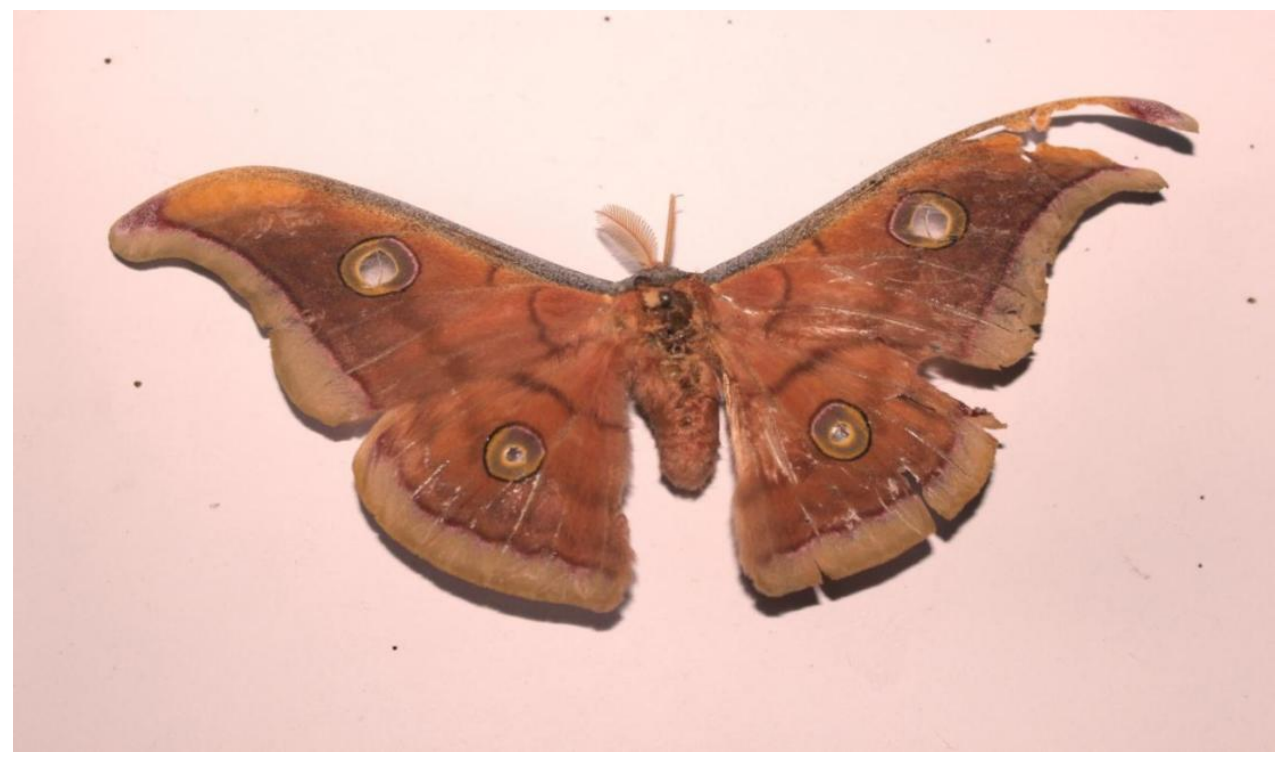

Fig 10:-Antheraea pernyi(Tussar moth/Oak Silkmoth)

\section{Asota caricae, Fabricius:-}

Status:- Rare

Wingspan:- 51-58 mm.

Diagnostic characters:- Buff forewings and black-spotted yellow hindwing. The body is yellow with a black mark on the top of each abdominal segment.

Distribution:- Found from the India and Indo-Australian tropics to Queensland and Vanuatu.

Host plant:- The larvae have been recorded on Ficus, Shorea species,Tectona and Mesuah. 


\section{Boarmiaspecies, Stephens:-}

Status:-Very common

Wingspan:- 40-48 mm.

Diagnostic characters:- the wings of this species are whitish-grey or yellowish, though they have a buff or grey appearance from a distance, as they are heavily speckled with brown or black dots. Running over the fore and hind wingsin a semi-circle are the two blackish bands, but they are broken and somewhat indistinct in this species.

Distribution:- It is a common species of Asia(India), Europe and adjacent regions. While it is found widely throughout Scandinavian countries viz. Denmark,Norway and Sweden, which have maritime climate.

Host plant:-The larvae are highly polyphagous. They eat foliage of a wide range of plants e.g, Tea(Camellia sinensis), Apple (Malus),Plums(Prunus), Birches(Betula), Sal(Shorea robusta) etc.

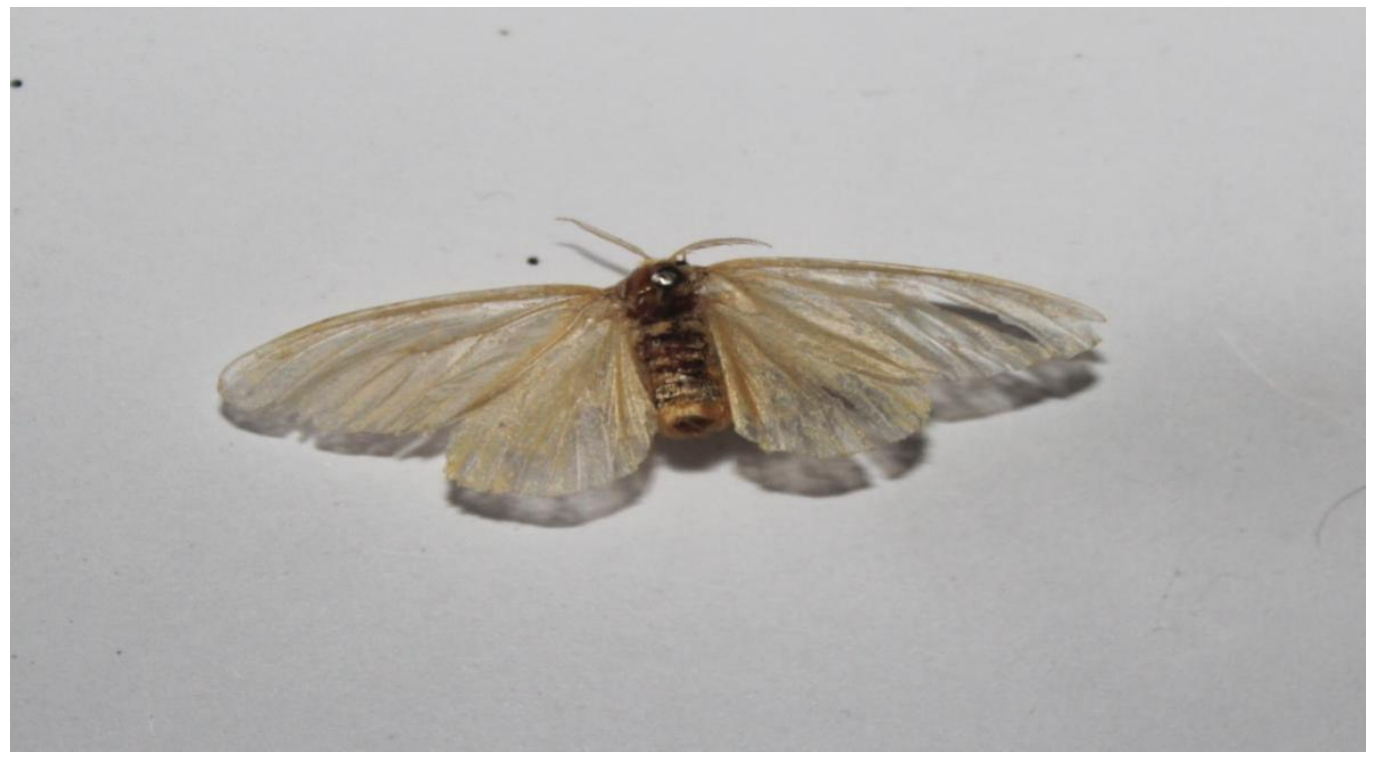

Fig 11:-Asota caricae. 


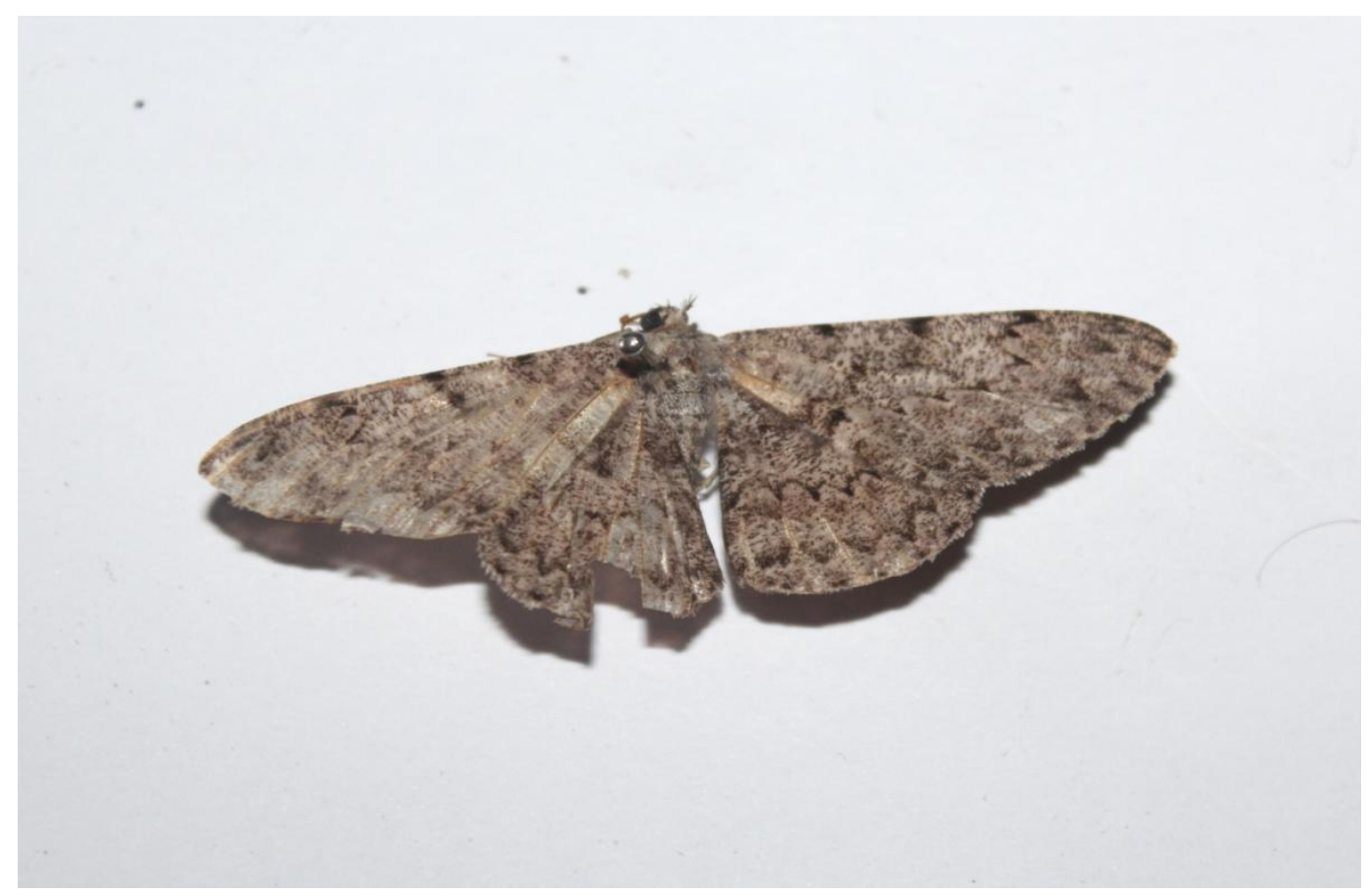

Fig 12:-Boarmia species.

\section{Comibaena cassidara (Guenee):-}

\section{Status:}

Wingspan:- 23-28 mm.

Diagnostic characters:- The forewing tornus and hindwing apex are only very narrowly rufous brown. The black discal spots are very small. The frewing has a faint, pale antemedial line.

Distribution:- Local to Borneo and globally distributed to India, China, Thailand, Singapore, Indonesia and Malaysia.

Host plant:- The larvae feed on the flower and young pods of Glycosmis. Some records are also found from plants like, Mangifera, cuscuta, Ziziphus, Shorea robustaand Anarcardium.

\section{Eupterote undata, Blanchard:-}

Status:- Common

Wingspan:- About $70 \mathrm{~mm}$ for females and $65 \mathrm{~mm}$ for males.

Diagnostic characters:- Adults are brownish-yellow or yellow with black double postmedial lines and various wavy black lines on the wings.

Distribution:- It is found in India, Pakistan, Sri Lanka, Myanmar, Sumatra, Java and the Philippines .

Host plant: The larvae feed on Elettaria(Cardamom), Eugenia hemispherica, Coffea Arabica(Coffee), Persea macrantha(Bay leave), Paulownia, Veronia arborea, Shorea robusta(Sal)and Maesa indica (Wild berry). 


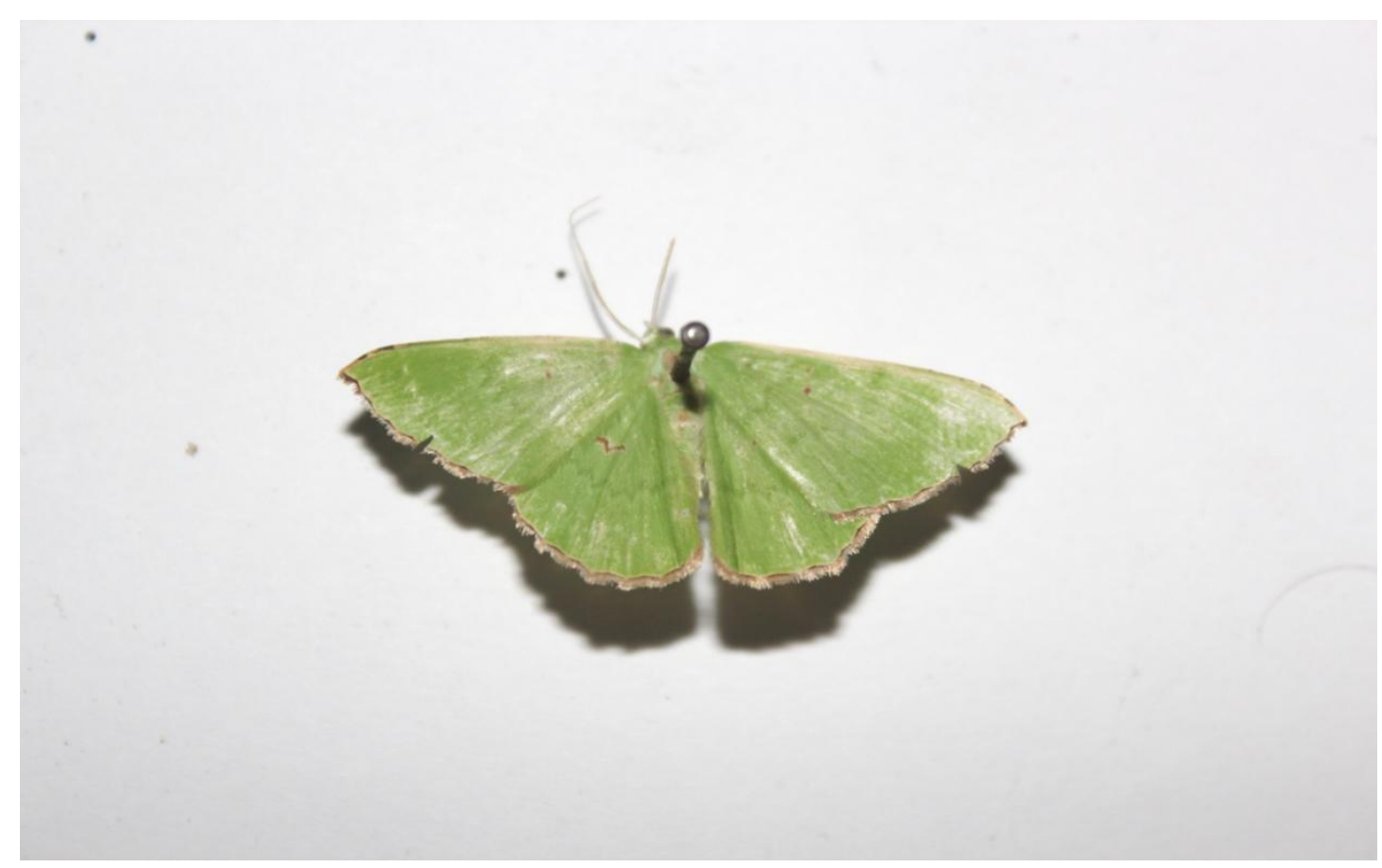

Fig 13:-Comibaena cassidara.

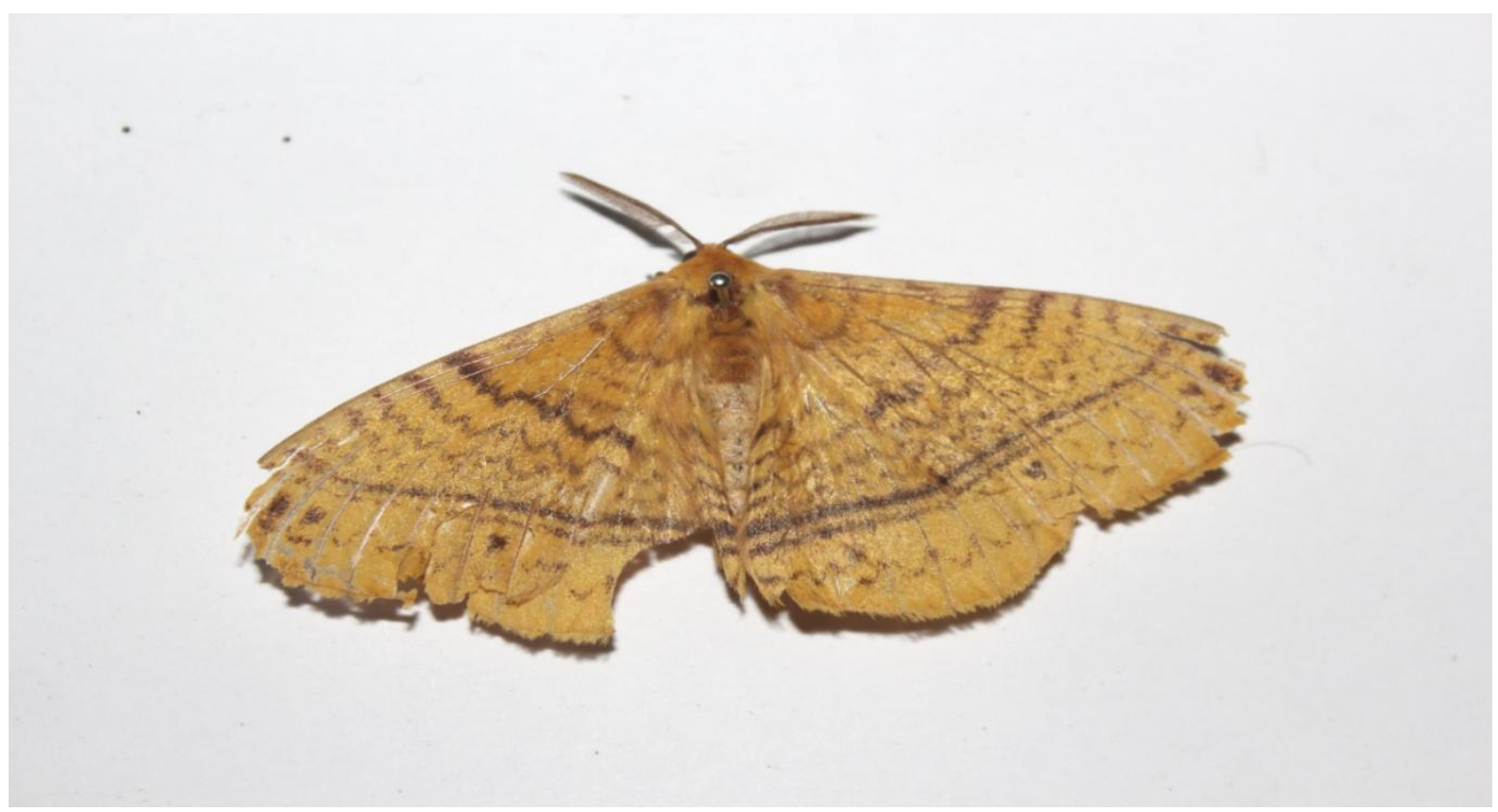

Fig 14:-Eupterotidae undata.

\section{Ganisa plana, Walker:-}

Status:- Common

Wingspan:- About $46 \mathrm{~mm}$.

Diagnostic characters:- The double postmedial of the forewing is not replicated on the hindwing. It lacks the oblique forewing shading.

Distribution:- Himalaya to South China and Sundaland, Palwan(Philippines).

Host plant:- The host plant recorded was Jasminum(Jasmine) and Shorea robusta(Sal). 


\section{Erebus hieroglyphica, (Drury):-}

Status:- Common

Wingspan: - male $84 \mathrm{~mm}$ and female $76 \mathrm{~mm}$.

Diagnostic characters:- Adults shows strong sexual dimorphism. In both sexes there is usually a pale cream to white bar at costa on the forewings, with a small pale patch in the centre of the wing.

Distribution:- Found globally India, sri lanka, Myanmar, Philippines, Malacca, java, ternate and Madagascar.

Host plant:- Recorded few specimens in softwood plantations. They have been reported feeding on juices of tropical fruits and on Shorea robusta.

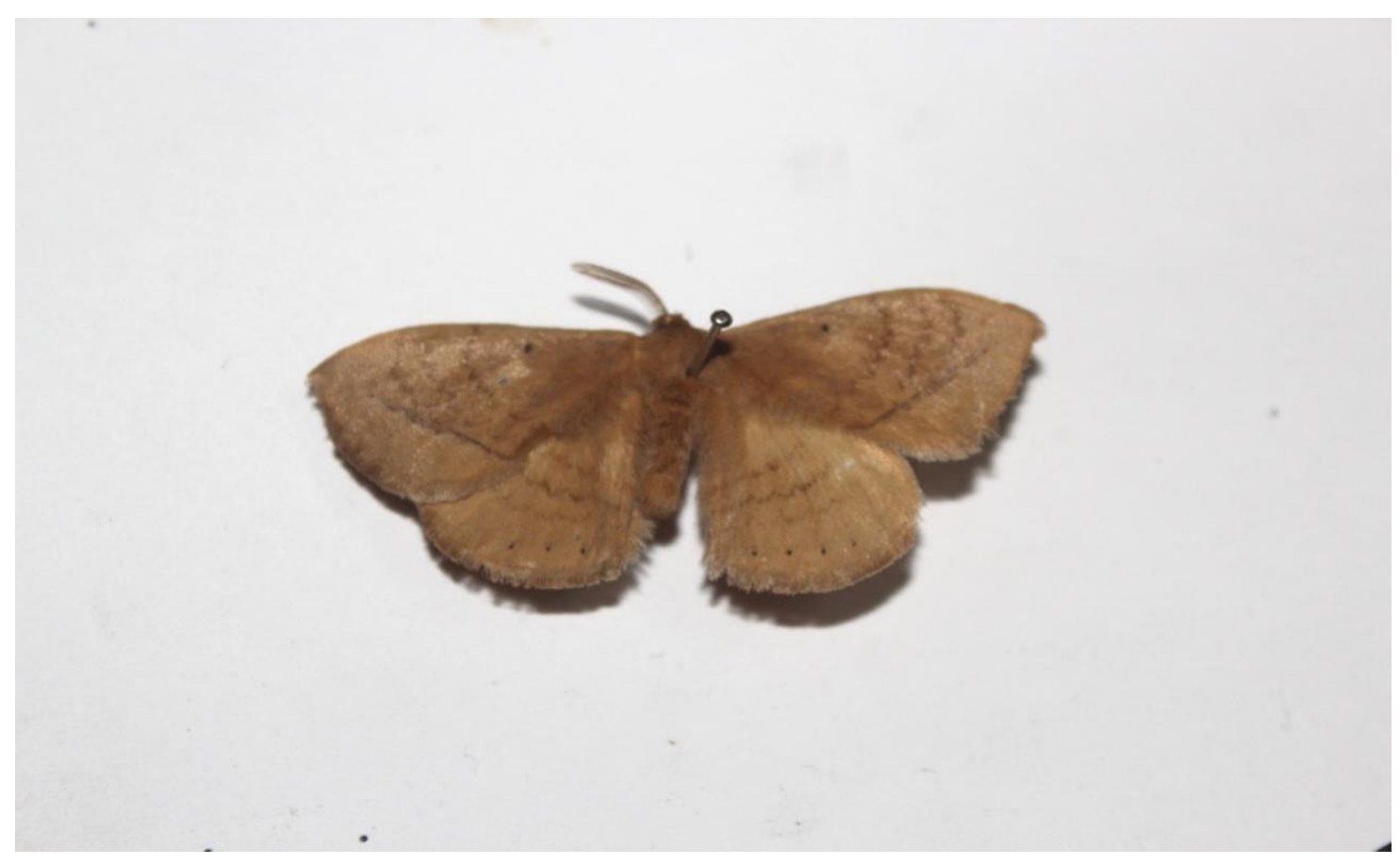

Fig 15:-Ganisa plana. 


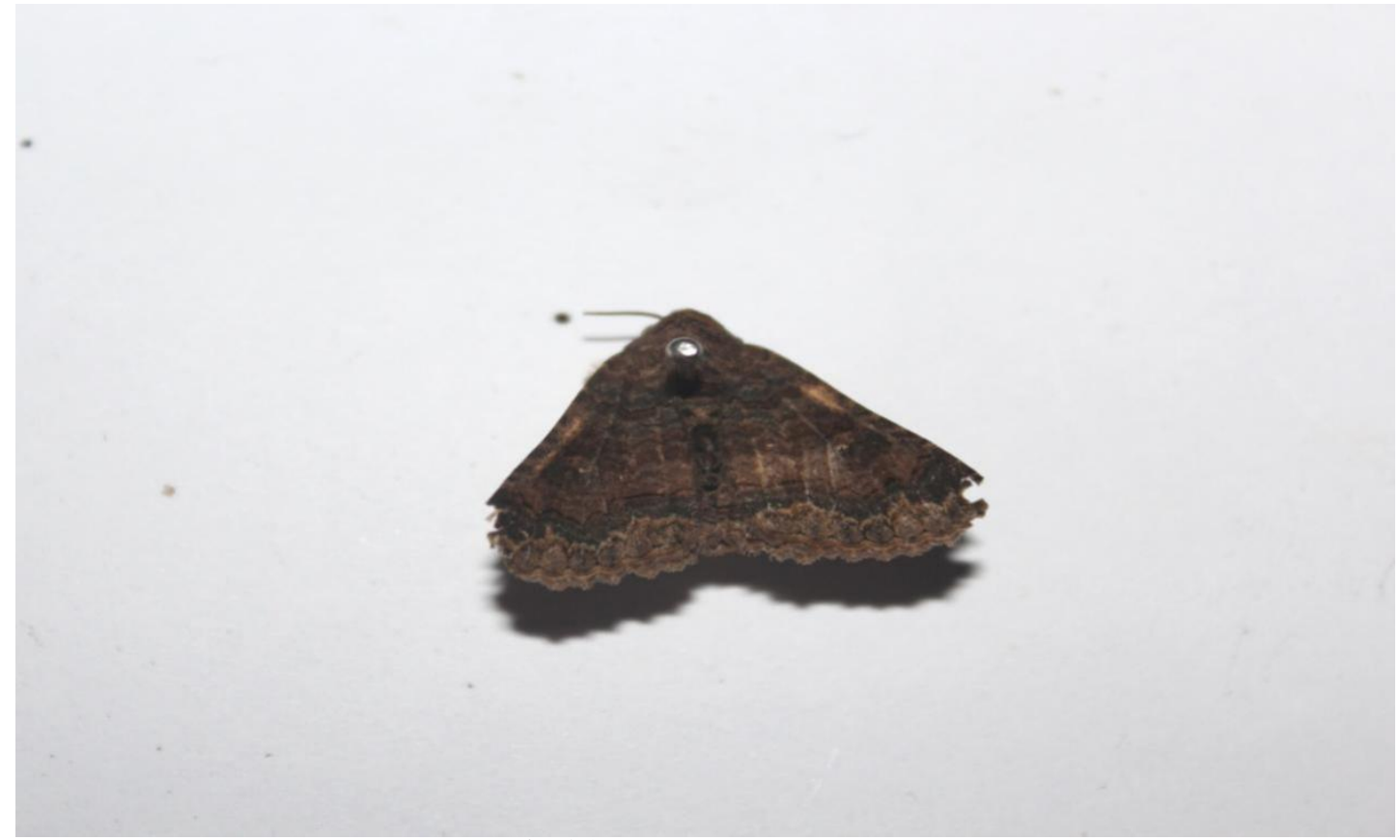

Fig 16:- Erebus hieroglyphica.

\section{Lemyra species, Walker:-}

Status:- Common

Wingspan:- Generally in between 24 to $40 \mathrm{~mm}$. some species may have upto $80 \mathrm{~mm}$.

Diagnostic characters:- The adult moths have forewing markings consist of oblique band and few scattered dots. Distribution:- Found from the East and South Asia(India), Sundaland and Australia.

Host plant:- Convolvulaceae, Dioscoreaceae and Leguminosae.

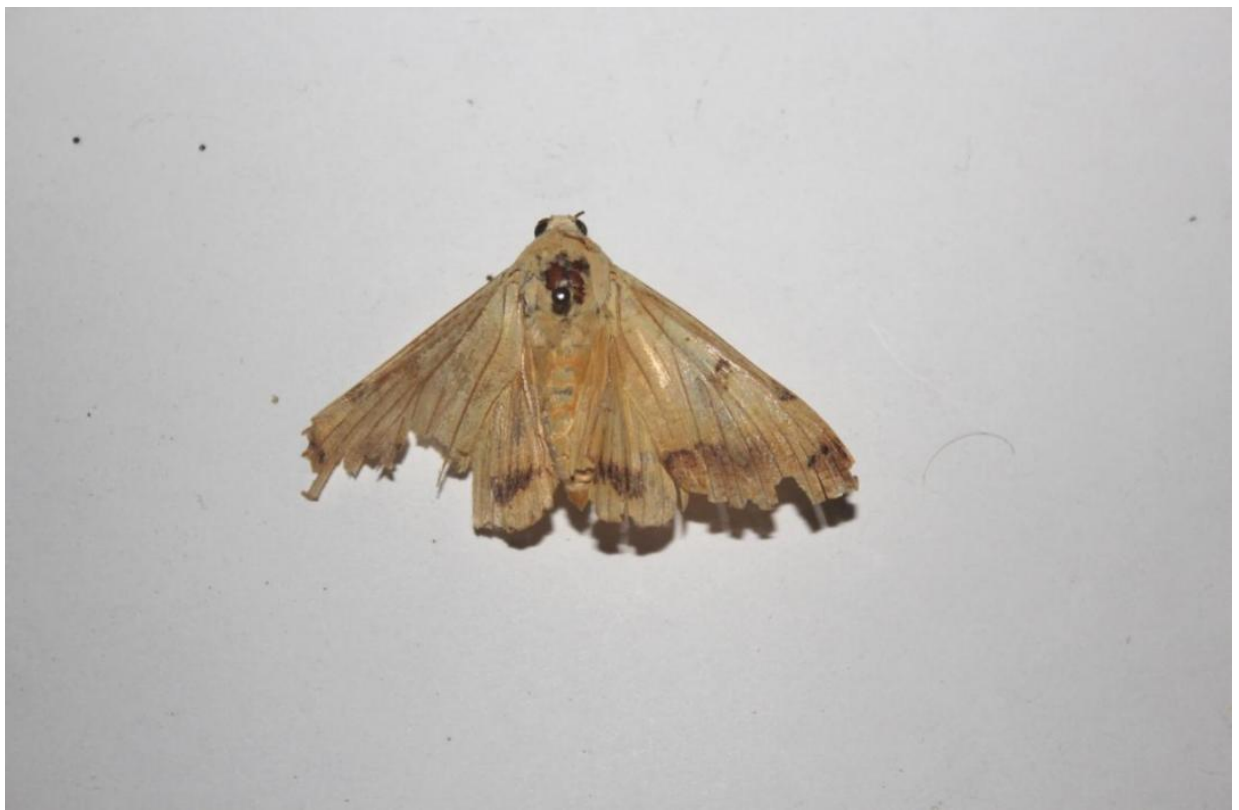

Fig 17:- Lemyra species. 


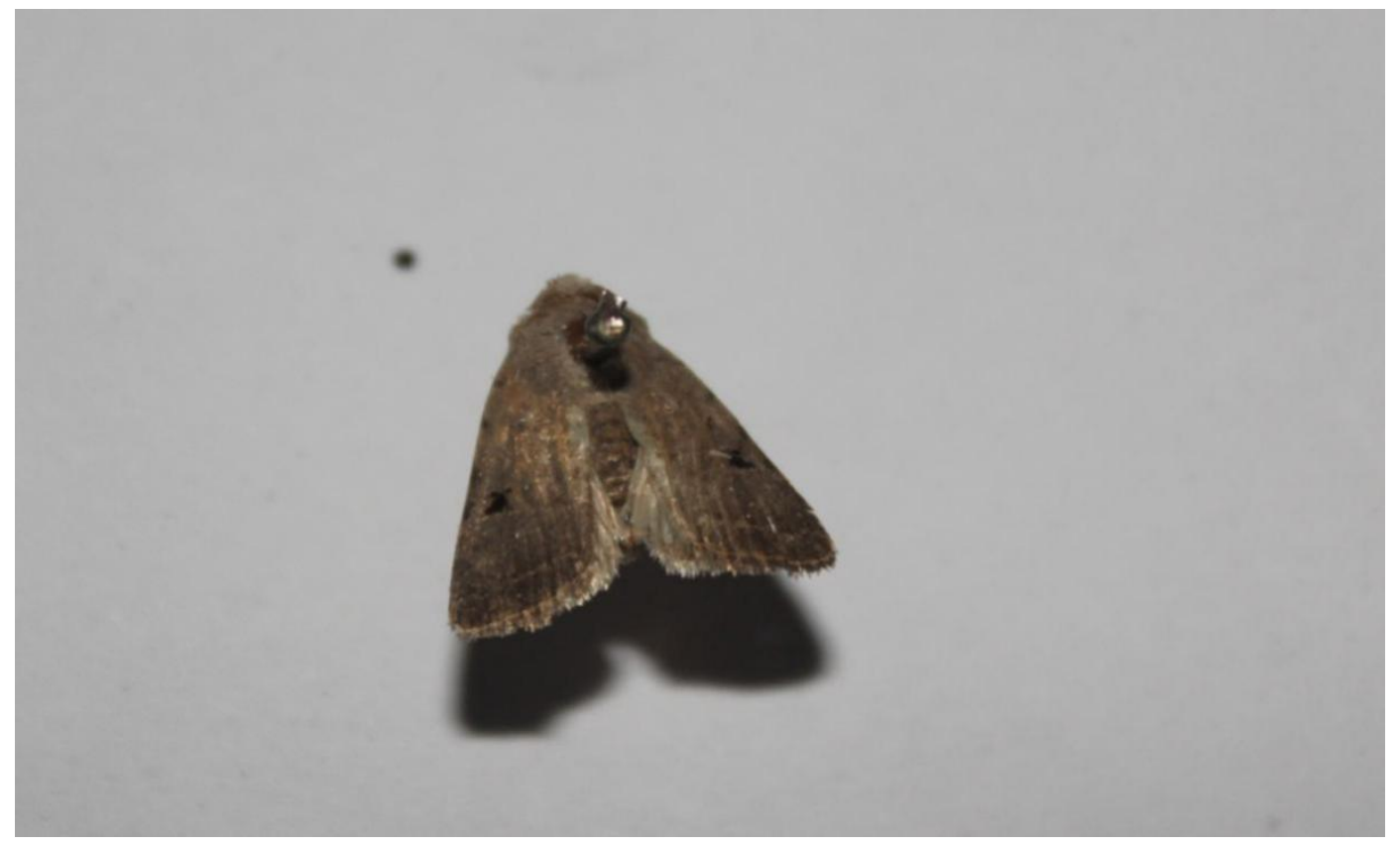

12 species of 6 different families(Fig 7-18) viz. Noctuidae, Geometridae, Saturniidae, Sphingidae, Erebidae \& Euteroptidae have been studied in which 2 species of Noctuidae, 2 species of Geometridae, 1 species of Saturniidae, 2 species of Sphingidae, 2 species of Euteroptidae and 3 species of Erabidae. However, Sondhi \& Sondhi (2016) explained checklist of moths of Dehradun, Moussoorie and Devalsari regions, which include the present work. Gurule \& Nikam (2013) explained the moths checklist (Lepidoptera:Heterocera) in Northern Maharastra. Sidhu et. al. (2010)has also explained about the above mentioned moths in a checklist of Macrolepidoptera of India. Rose and Pooni (2004) also explained taxonomic studies on the superfamily Pterophoroidea (Lepidoptera) from Northern India. Although Smetacek (1994, 2008, 2009, 2011),Koren., et al, (2015), Aslam, (2009), Kim \& Yoo, (2012), Brehm, (2005), Chandra., et al. (2013), Gadhikar, et al, (2013),Dey et al., (2015) and Sanyal ., et al, (2013) has studied moths on different areas.

\section{References:-}

1. Aslam, M., (2009). Diversity, Species Richness and evenness of moth fauna of Peshawar. Department of Zoology, Islamia College University Peshawar, NWFP, Pakistan. Pak. Entomol. Vol. 31(2):99-102.

2. Bell and Scott, (1937). The Fauna of British India Including Ceylon and Burma. Taylor and Francis, LTD. Red Lion court.QL556, H23X, Vol.5 Ent:1-533.

3. Brehm, G., (2005). Diversity and community structure of geometrid moths of disturbed habitat in a montane area in the Ecuadorian Andes. Department of Animal Ecology I, University of Bayreuth, Germany. Journal of research on the Lepidoptera. 38:1-14

4. Chandra, Roshni Pandey, Rita Bhandari \& S. Sambath (2013). Diversity of Hawk KailashMoths (Lepidoptera: Sphingidae) in VeeranganaDurgavati Wildlife Sanctuary, Damoh, Madhya Pradesh., An International Journal (1): 573-77 (2013).

5. Dey, P., Uniyal, V.P.,Saniyal, A. K. , (2015). Moth assemblage (Lepidoptera: Heterocera) as a potential conservation tool for biodiversity monitoring- study in Western Himalayan protected areas. The Indian Forester(founded in 1875).141 (9):1-135.

6. Gadhikar, Y.A., et al., (2013). A preliminary Report on Moths (Insecta:Lepidoptera:Heterocera) fauna from Amravati, Maharastra. International Journal of Science and Research (IJSR). ISSN(Online): 2319-7064

7. Gurule, S.A., Nikam, S.M., (2013). The moths(Lepidoptera) of Northern Maharashtra: A preliminary checklist. Journal of threatened taxa.5(12):4693-4713.

8. Kim; Yoo, et al., (2012). Moth fauna of Biguenmdo Island in korea. National Science museum of korea. Journal of Asia-Pacific Biodiversity. Vol.5(1), 089

9. Koren. T, et al, (2015). Diversity of moth fauna (Lepidoptera: Heterocera) of a wetland forest: A case study from Motovun forest, Istria, Croatia. Periodicum Biologorum. 117(3):399-414. 
10. Kumar, A. (2013). Butterfly (Lepidoptera: Insecta) Diversity from different sites of Jhagadia, Ankleshwar, District-Bharuch, GujaratInternational Peer-Reviewed JournalOct. Jour. Env. Res. Vol. 1(1):09-18.

11. Rose and Pooni, (2004). Taxonomic studies on the superfamily Pterophoroidea (Lepidoptera) from Sri Lanka.

12. Sanyal, A. K., Uniyal, V.P.,Chandra,K. and Bhardwaj, M. (2013). Diversity, Distribution pattern and seasonal variation in moth assemblages along altitudinal gradient in Gangotri landscape area, Western Himalaya, Uttarakhand, India., Journal of threatened Taxa, 5(2):3646-3653.

13. Sidhu, A.K., K. Chandra \& P.C. Pathania (2010). A Check-list of Macrolepidoptera of India (Part-I: Family Pterophoridae), 1-12pp. <http://zsi.gov.in/checklist/Family\%20Pterophoridae.pdf> Online version accessed January 2010.

14. Smetacek, P. (1994). Hawkmoths (Lepidoptera, Sphingidae) of Kumaon, N. India : A probable case of faunal Drift. Records of the Zoological Survey of India (Occasional Paper) 156: 1-55.

15. Smetacek, P. (2009). Additions and corrections to the list of moths recorded from different elevations in Nainital District, Kumaon Himalaya, India. Bionotes 11(4): 117-118.

16. Smetacek, P. (2011). Further Additions to the Moths (Lepidoptera: Heterocera) of Nainital District, Kumaon Himalaya, India. Bionotes 13(4): 140-141.

17. Smetacek, P. (2008). Moths recorded from different elevations in Nainital District, Kumaon Himalaya, India. Bionotes 10(1): 5-15.

18. Sondhi, Yash., Sondhi, Sanjay, (2016). A partial checklist of Moths(Lepidoptera) of Dehradun, Mussoorie and Devalsari in Garhwal, Uttarakhand, India. Journal of threatened taxa. 8(5):8756-8776. 